\title{
Autochthonous dengue virus infection in Japan imported into Germany, September 2013
}

J Schmidt-Chanasit (jonassi@gmx.de) ${ }^{1,2}$, P Emmerich ${ }^{1}$, D Tappe ${ }^{1}$, S Günther $^{1}$, S Schmidt ${ }^{3}$, D Wolff ${ }^{3}$, K Hentschel ${ }^{4}$, D Sagebiel ${ }^{4}$,

I Schöneberg ${ }^{5}$, K Stark S $^{5}$ C Frank ${ }^{5}$

1. Bernhard Nocht Institute for Tropical Medicine, WHO Collaborating Centre for Arbovirus and Haemorrhagic Fever Reference and Research, Hamburg, Germany

2. German Centre for Infection Research (DZIF), partner site Hamburg-Luebeck-Borstel, Hamburg, Germany

3. Public Health Authority Steglitz-Zehlendorf, Berlin, Germany

4. State Office of Health and Social Affairs, Berlin, Germany

5. Robert Koch Institute, Department for Infectious Disease Epidemiology, Division of Gastrointestinal Infections, Zoonoses and Tropical Infections, Berlin, Germany

Citation style for this article:

Schmidt-Chanasit J, Emmerich P, Tappe D, Günther S, Schmidt S, Wolff D, Hentschel K, Sagebiel D, Schöneberg I, Stark K, Frank C. Autochthonous dengue virus infection in Japan imported into Germany, September 2013. Euro Surveill. 2014;19(3):pii=20681. Available online: http://www.eurosurveillance.org/ViewArticle. aspx?Articleld $=20681$

Article submitted on 18 January 2014 / published on 23 January 2014

In September 2013, dengue virus (DENV) infection was diagnosed in a German traveller returning from Japan. DENV-specific IgM and IgG and DENV NS1 antigen were detected in the patient's blood, as were DENV serotype 2-specific antibodies. Public health authorities should be aware that autochthonous transmission of this emerging virus may occur in Japan. Our findings also highlight the importance of taking a full travel history, even from travellers not returning from tropical countries, to assess potential infection risks of patients.

Here we report the clinical and laboratory findings of a dengue virus (DENV) infection acquired in Japan in late summer 2013 and imported into Germany.

\section{Case description}

A previously healthy woman in her early 50 s sought treatment in a hospital in Berlin, Germany, in September 2013 after returning from travel to Honshu Island, Japan. For the previous six days, she had been suffering from fever (up to $40^{\circ} \mathrm{C}$ ) and nausea, followed by a maculopapular rash. Laboratory tests on the day of admission showed elevated levels of glutamateoxalate transaminase (GOT) (96 units (U)/L; norm: $<35$ $\mathrm{U} / \mathrm{L}$ ), glutamate pyruvate transaminase (GPT) (52 U/L; norm: $335 \mathrm{U} / \mathrm{L})$, creatine kinase (CK) (553 U/L; norm: (170 U/L) and lactate dehydrogenase (LDH) (299 U/L; norm: $<250 \mathrm{U} / \mathrm{L}$ ). Leukopenia (white blood cell count: 3.2 G/L; norm: 4.4-11.3 G/L) was present, which intensified the following day $(3.1 \mathrm{G} / \mathrm{L})$. In addition, thrombocytopenia, with a platelet count of $87 \mathrm{G} / \mathrm{L}$ (norm: 177-393 G/L) was present, which intensified the following day as well $(79 \mathrm{G} / \mathrm{L})$.

Nine days before admission, she had returned from a two-week trip to Japan, during which she visited Ueda, Fuefuki, Hiroshima, Kyoto and Tokyo in August. She reported several mosquito bites while grape picking in Fuefuki. She flew nonstop from Frankfurt International
Airport to Tokyo Narita International Airport and came back the same way. The patient was vaccinated against yellow fever in 2009, because she had travelled to Kenya that year. In the beginning of 2012, she travelled to Singapore. Among several other diseases, dengue fever was suspected, because of the clinical picture.

The first serum sample, collected seven days after symptom onset, gave a positive result in DENV IgM and IgG antibody tests (in-house indirect immunofluorescence assay (IIFA), according to [1-3]), as well as for DENV nonstructural protein-1 (NS1) antigen tested by ELISA (Bio-Rad Platelia Dengue $\mathrm{NS}_{1} \mathrm{Ag}$ ) and a rapid test (SD BIOLINE Dengue Duo NS1 Ag + Ab Combo), demonstrating an acute DENV infection (Table). Realtime RT-PCR for DENV RNA [4] and generic flavivirus RT-PCR [5] were negative.

The thrombocytopenia resolved without complications and after one week in hospital, the patient was discharged with a characterisation of restitutio ad integrum (restoration to original condition). A follow-up serum sample was collected in December 2013, 110 days after symptom onset, because this acute case of dengue fever imported from Japan was considered very unusual. This second serum sample revealed a significant decrease in DENV IgG titre in the IIFA and negative results for DENV NS1 antigen (ELISA and rapid test) and DENV IgM (IIFA and rapid test) (Table). In order to identify the causative DENV serotype, an immune complex binding ELISA [6] was performed on the second serum sample, demonstrating the presence of DENV serotype 2-specific antibodies (Table) and the absence of DENV serotype 1-, 3- and 4-specific antibodies, thus excluding a secondary DENV infection.

\section{Background}

DENV is an arthropod-borne RNA virus of the Flaviviridae family causing dengue fever in humans. Aedes aegypti 
TABLE

Serological results of case of autochthonous dengue virus infection in Japan imported into Germany, September 2013

\begin{tabular}{|c|c|c|}
\hline \multirow{2}{*}{$\begin{array}{l}\text { Antibody or antigen } \\
\text { tested }\end{array}$} & \multicolumn{2}{|c|}{$\begin{array}{l}\text { Serum samples taken after } \\
\text { symptom onset (days) }\end{array}$} \\
\hline & 7 & 110 \\
\hline Anti-DENV-IgGa & $1: 20,480$ & $1: 640$ \\
\hline Anti-DENV-IgMa & $1: 320$ & $<1: 20$ \\
\hline DENV NS $1^{b}$ & $\begin{array}{c}\text { Positive } \\
\text { (5.1 arbitrary units) }\end{array}$ & $\begin{array}{c}\text { Negative } \\
\text { (0.2 arbitrary units } \\
\end{array}$ \\
\hline DENV serotype ${ }^{c}$ & Not tested & DENV 2 \\
\hline Anti-JEV-IgGa & $1: 20,480$ & $1: 640$ \\
\hline Anti-JEV-IgM ${ }^{a}$ & $\ll 1: 20$ & $\ll 1: 20$ \\
\hline Anti-WNV-IgG ${ }^{a}$ & $1: 5,120$ & $1: 1,280$ \\
\hline Anti-WNV-IgM ${ }^{\mathrm{a}}$ & $<1: 20$ & $\ll 1: 20$ \\
\hline Anti-YFV-IgGa & $1: 5,120$ & $1: 640$ \\
\hline Anti-YFV-IgM ${ }^{a}$ & $\langle 1: 20$ & $\ll 1: 20$ \\
\hline Anti-TBEV-IgG ${ }^{a}$ & $1: 640$ & $1: 320$ \\
\hline Anti-TBEV-IgM ${ }^{a}$ & $<1: 20$ & $<1: 20$ \\
\hline
\end{tabular}

DENV: dengue virus; JEV: Japanese encephalitis virus; TBEV: tickborne encephalitis virus; WNV: West Nile virus; YFV: yellow fever virus.

${ }^{a}$ Indirect immunofluorescence assay (IIFA) titres $\$ 1: 20$ for serum were considered negative [1-3].

b SD BIOLINE Dengue Duo NS1 Ag + Ab Combo and Bio-Rad Platelia Dengue NS1 Ag.

' Immune complex binding ELISA [6].

(Linnaeus) and Ae. albopictus (Skuse) mosquitoes are considered to be the main vectors of DENV worldwide [7]. DENV has emerged in recent decades as a worldwide public health problem: current estimations assume 390 million DENV infections per year, with 96 million clinically apparent cases [7]. The virus is found in tropical and subtropical regions around the world, with hyper-endemic areas in Central and South America and in south-east Asia. It is considered an emerging threat to Europe because of its detection in Croatia (2010) and France (2010 and 2013) $[1,8,9]$. Ae. albopictus is considered to be the potential vector for DENV in these countries: it is an invasive species in Europe and was recently detected in the south-western and south-eastern parts of Germany $[10,11]$.

In Germany, dengue fever is notifiable and 870 imported cases were reported in 2013, with the majority of cases imported from south and south-east Asia [12]. There is no evidence for autochthonous transmission in Germany.

In Japan, Ae. albopictus is well established and distributed widely, with its northern limits on Honshu Island between latitude $38^{\circ}$ to $40^{\circ}$ north [13]. Moreover, Ae. aegypti is also invasive in Japan and was detected during entomological surveillance at Tokyo Narita
International Airport in 2012 [14]. The last notable dengue fever outbreak in Japan occurred in 1942 to 1945 in Nagasaki, Kyushu Island, and spread in 1944 to cities on Honshu Island such as Hiroshima and Osaka [15]. This was the most widespread dengue epidemic recorded in a temperate region, involving at least 200,000 cases [16]. It was suggested that the principal vector was Ae. albopictus [13]. However, no autochthonous cases of dengue infection have been reported since 1945 [16]. According to Japanese notification data, 249 imported DENV infections were reported in 2013 [17]. The reported DENV infections were mainly caused by DENV serotype 1 [17].

\section{Conclusions}

This is the first laboratory-confirmed case of DENV infection imported from Japan to Germany and, to the best of our knowledge, the first recognised case of locally acquired DENV infection in Japan for more than 60 years. Most likely, according to the patient's activities and DENV incubation period (3-14 days [18]), the infection was acquired in Fuefuki during grape picking. However, other possible places of infection cannot be entirely ruled out including Tokyo Narita International Airport. Thus, we suggest that a viraemic patient was bitten by a competent mosquito (most likely Ae. albopictus) in the geographical area where our patient was picking fruit, leading to the amplification of DENV serotype 2 in the local mosquito population. Such an event was probably the source of the virus that infected our patient.

This case adds important epidemiological data that can be used to refine DENV risk assessments in Japan. Consequently, the Ministry of Health, Labour and Welfare of Japan was informed via the International Health Regulations National Focal Point about the case. Public health authorities, blood transfusion services and clinicians in Japan should consider the risk of autochthonous DENV infections, especially during the summer. Our findings also highlight the importance of taking a full travel history, even from travellers who do not return from tropical countries, in order to assess potential infection risks of the patients [18].

\section{Acknowledgments}

We would like to thank Alexandra Bialonski, Insa Bonow, Corinna Thomé, Birgit Hüsing and Sabine Köhler for technical assistance. We are grateful to Kazuko Fukushima and Tomohiko Takasaki for providing additional information regarding this case.

\section{Conflict of interest}

None declared.

\section{Authors' contributions}

Wrote the manuscript: JSC, SG, DT, CF, KS, DS, IS; performed laboratory or epidemiological investigations: JSC, PE, KS, CF, DS, SS, DW, KH, DS; performed data analysis: JSC, PE, CF. 


\section{References}

1. Schmidt-Chanasit J, Haditsch M, Schoneberg I, Gunther S, Stark K, Frank C. Dengue virus infection in a traveller returning from Croatia to Germany. Euro Surveill. 2010;15(40):pii:19677. Available from: http://www.eurosurveillance.org/ViewArticle. aspx?Articleld $=19677$

2. Schmidt-Chanasit J, Tenner-Racz K, Poppert D, Emmerich P, Frank C, Dinges C, et al. Fatal dengue hemorrhagic fever imported into Germany. Infection. 2012;40(4):441-3. http://dx.doi.org/10.1007/s15010-011-0208-3

3. Tappe D, Schmidt-Chanasit J, Ries A, Ziegler U, Müller A, Stich A. Ross River virus infection in a traveller returning from northern Australia. Med Microbiol Immunol. 2009;198(4):2713. http://dx.doi.org/10.1007/s00430-009-0122-9

4. Johnson BW, Russell BJ, Lanciotti RS. Serotype-specific detection of dengue viruses in a fourplex real-time reverse transcriptase PCR assay. J Clin Microbiol. 2005;43(10):4977-83 http://dx.doi.org/10.1128/JCM.43.10.4977-4983.2005

5. Chao DY, Davis BS, Chang GJ. Development of multiplex real-time reverse transcriptase PCR assays for detecting eight medically important flaviviruses in mosquitoes. J Clin Microbiol. 2007;45(2):584-9. http://dx.doi.org/10.1128/JCM.00842-06

6. Emmerich P, Mika A, Schmitz H. Detection of serotypespecific antibodies to the four dengue viruses using an immune complex binding (ICB) ELISA. PLoS Negl Trop Dis. 2013;7(12):e2580. http://dx.doi.org/10.1371/journal.pntd.0002580

7. Bhatt S, Gething PW, Brady OJ, Messina JP, Farlow AW, Moyes $\mathrm{CL}$, et al. The global distribution and burden of dengue. Nature. 2013;496(7446):504-7. http://dx.doi.org/10.1038/nature12060

8. La Ruche G, Souarès $Y$, Armengaud A, Peloux-Petiot F, Delaunay $P$, Desprès $P$, et al. First two autochthonous dengue virus infections in metropolitan France, September 2010. Euro Surveill. 2010;15(39):pii=19676. Available from: http://www. eurosurveillance.org/ViewArticle.aspx?Articleld=19676

9. Marchand E, Prat C, Jeannin C, Lafont E, Bergmann T, Flusin O, et al. Autochthonous case of dengue in France, October 2013. Euro Surveill. 2013;18(50):pii=20661. Available from: http:// www.eurosurveillance.org/ViewArticle.aspx?Articleld=20661

10. Becker N, Geier M, Balczun C, Bradersen U, Huber K, Kiel E, et al. Repeated introduction of Aedes albopictus into Germany, July to October 2012. Parasitol Res. 2013;112(4):1787-90. http://dx.doi.org/10.1007/s00436-012-3230-1

11. Kampen H, Kronefeld M, Zielke D, Werner D. Further specimens of the Asian tiger mosquito Aedes albopictus (Diptera, Culicidae) trapped in southwest Germany. Parasitol Res. 2013;112(2):905-7. http://dx.doi.org/10.1007/s00436-012-3128-y

12. Robert Koch Institute (RKI). SurvStat@RKI. Berlin: RKI. [Accessed 23 Jan 2014]. German. Available from: http://www3. rki.de/SurvStat

13. Kobayashi M, Nihei N, Kurihara T. Analysis of northern distribution of Aedes albopictus (Diptera: Culicidae) in Japan by geographical information system. J Med Entomol. 2002;39(1):4-11. http://dx.doi.org/10.1603/0022-2585-39.1.4

14. Sukehiro N, Kida N, Umezawa M, Murakami T, Arai N, Jinnai T, et al. First report on invasion of yellow fever mosquito, Aedes aegypti, at Narita International Airport, Japan in August 2012 Jpn J Infect Dis. 2013;66(3):189-94. http://dx.doi.org/10.7883/yoken.66.189

15. Takasaki T. Imported dengue fever/dengue hemorrhagic fever cases in Japan. Trop Med Health. 2011;39(4 Suppl):13-5. http://dx.doi.org/10.2149/tmh.2011-S07

16. Gratz NG. Critical review of the vector status of Aedes albopictus. Med Vet Entomol. 2004;18(3):215-27. http://dx.doi.org/10.1111/j.0269-283X.2004.00513.x

17. National Institute of Infectious Diseases, Laboratory of VectorBorne Viruses, Japan. [Dengue virus infection information]. [Accessed 23 Jan 2014]. Japanese. Available from: http:// wwwo.nih.go.jp/vir1/NVL/dengue.htm

18. Schmidt-Chanasit I, Schmiedel S, Fleischer B, Burchard GD. Viruses acquired abroad: what does the primary care physician need to know? Dtsch Arztebl Int. 2012;109(41):681-91. 